\title{
2 The Context
}

In this book Vergil's political views and the topics of Vergil writing propaganda for Octavian (later for Augustus) are discussed. Before analysing the poems in detail, the background against which Vergil worked will be examined: which political message did he want to convey, if any, and whom did he want to reach? It cannot be taken for granted that he wrote propaganda, but if this was the case did he write for Augustus who wanted different strata of the population to accept his policies and if so, which groups did he have in mind? Was it the population at large that he wanted to convince, not only at Rome but also in the provinces? Or was he only interested in the elite, that is, the opinion leaders?

In this chapter I will examine two main topics: (1) whether poetry in general was suitable for a propaganda tool for the person and policies of Octavian/Augustus, and (2) whether Vergil's (and other poets') audiences were the right candidates for the reception of such putative propaganda. This leads to several questions about the context in which Vergil worked, not just in az general sense, such as the course of the struggle for power after 44 B.C. and the political developments at Rome, but also, more specifically, in relation to the audiences for which he wrote. Of course these can not be investigated in detail in a study like this. However, an overview will be presented in this chapter and some appropriate aspects will be discussed in the following sections ${ }^{29}$.

The chapter is structured as follows. In section 2.1, I will briefly discuss some general aspects of Augustan poetry, such as the influence of archaic Greek and Hellenistic literature, the use of references, and poetic representation. This will be followed, in the same section, by a brief overview of the use of visual media in Rome and Italia in the Late Republic and the Early Empire. I will explore whether visual images served more widely as instruments of representation of power and of propaganda and I will examine the relationship between poetry and visual media. In section 2.2, issues like levels of literacy, education and the likely audiences in the public and private area will be briefly discussed. Next, in section 2.3 patronage will be considered. Most of the established poets belonged to the circles of different leading figures, for instance Maecenas and Messalla, whom are often said to have been instrumental in putting pressure on the poets to write propaganda. This chapter will close with a summary and with some conclusions on the suitability of poetry in a supposed programme of propaganda (section 2.4).

29 I have not included a section about the historicaI context. I refer to a number of recent general textbooks and specialised books which deal with the Late Republic and the Augustan Age, such as: Boatwright, Gargola \& Talbert (2004, 267-316); Bowman, Champlin \& Lintott, 1996; Brunt, 1988; Crook, Lintot \& Rawson, 1994; Earl, 1968; Galinsky (1996, 80-140); Galinsky, 2005; Hekster (2009, 25-68); Raaflaub \& Toher, 1993; Stahl, 1998; Wallace-Hadrill, 2005; Yavetz (1993, 21-41); Zanker, 2010. 


\subsection{Poetry And Visual Media In The Late Republic And Early Empire}

Augustan poetry was not created in a vacuum, but had its roots in the Latin literary tradition with its many Classical Greek and Hellenistic influences, and existed in conjunction with thearts in general, which in turn consisted of an intricate construction of tradition, taste and fashion, foreign influence (again mainly from Greece and the Hellenistic world), politics, social and economic developments and other elements. I will consider parallels between Augustan poetry and the visual media of that period both in the public space and in the private domain. In the public space there were the portraits, statues, and reliefs forming part of the new urban design and restoration programme by Augustus, and coins. The first three of these were generally erected in Rome and in the major cities of the empire, while coins were used and minted through all the lands under Roman rule. The public readings of poetry, which occasionally took place, also belong to the public domain. In the private domain one finds, among other things, mural paintings and ornamental pieces, vases and goblets. To this domain also belong readings of poetry in private or small gatherings, for instance at a meal or at a symposion.

Some general aspects of Latin poetry in the Augustan age will be discussed first, followed by some characteristics of visual media, in particular the way in which it was used to refer to contemporary issues.

In the Republican age Greek literary creations served as sources of inspiration for Roman authors. In the beginning there was much experimentation. What were originally Greek metres were applied to a modified Latin language, Greek mythical subjects were reworked and Greek poetic genres were adopted by Latin authors. The end of the Republic saw the rise of the poetae novi or Neoterici, of whom Catullus (about 84-54 B.C.) was the most important. They formed as it were an artistic bridge between Greek Hellenistic and Latin poetry and they no longer wrote grand poetry such as epic, but concentrated on poetry whose subject matter was to be found in their own microcosm and in which they could express their own feelings. Genres such as elegiac and lyric poetry became the vogue. Hellenistic poetry was obviously a new discovery found as a result of Roman military expansion, and as such formed the second source of inspiration. Towards the end of the first century B.C. these two main sources often resulted in poems in which many Greek archaic - for instance Alcaeus or Pindar - and Hellenistic poets - for instance Callimachus - can be traced.

Although poetry in the Augustan age remained under the influence of Republican tradition, it developed into a very sophisticated form and showed a high degree of involvement with contemporaneous issues. "The poets, then, were creative participants in the ongoing discussion about ideals and values, and they had their own minds about them" (Galinsky, 1996, 225). Bowra $(1945,34)$ notes that the Aeneid had helped many to see the main problems of life. A major characteristic of Augustan poetry was what Galinsky (1996, 229-234) describes as "complexity and multiplicity of meanings” (see also Conte, 1986, 23-31). The Augustan poets made reference to Greek 
mythical figures who were then given a place in contemporary events. The choice of references would also indicate the poet's approval or disapproval of a certain issue, and the audience was able to understand this. Thus, one could read or listen to a poem on different levels. The "aesthetic" level consisted of appreciating the characters in the poem on their own poetic merits and experiencing the beauty of their personalities or actions. On the "associative" level, the reader's thoughts were directed towards the events and issues of the day, whereby the reader or listener would often be invited to contemplate moral or ethical questions. Later in this book I will argue that the poets of the Augustan age made extensive use of several forms of references and associations. The use of references was not exclusive to the poets: it was common in Roman art in general, and references were widely used also in the visual arts (see below). The significance of references, therefore, canot be over-estimated.

Before moving on, it is worth considering whether the poets expressed their own opinions about political or social issues or whether their views were a result of the performative stance which they took. This has been examined in great detail in a recent book by Lowrie (2009, vii), who opens her book as follows:

This book argues that the power poets attribute to words in Augustan Rome is intimately related to the language they use to describe the representing media. Although interest in the relation of the means of representation to power can be traced to the earliest Roman poetry, the historical crisis of the transition from Republic to Empire opened new avenues for literary production and offered fertile ground for an examination of the modes of cultural production, their respective powers and inadequacies.

Not all the avenues which Lowrie explores can be discussed in this book. I want to focus very briefly on the phenomenon of personae, about which Lowrie $(2009,102)$ remarks: “In Oliensis’ words (1998:1-2), 'Horace’s poetry is itself a performance venue... Horace is present in his personae, that is, not because these personae are authentic and accurate impressions of his true self, but because they effectively construct that self."' Lowrie adds that a similar point can be made regarding the poem's address. She acknowledges the difficulty of the question whether the poets perform or teach, when she states: "Can it [poetry] teach (Epist. 2.1.124-8)? Horace repeatedly makes the gesture of poetic efficacy, and repeatedly pulls it back. Performativity is a topic, but does poetry actually perform?"30 (Lowrie 2009, 103). However, the choice of the performative medium determines the effectiveness. Lowrie $(2009,215)$ makes this point for literature: "Closeness to the word of god, an active intervention in society, pragmatic effectiveness - the advantages of literature figured as song, as living presence [contrary to the writing of letters], as performative in all the word's senses overwhelm and seduce."

30 Lowrie (2009, 101-111). A different view can be found in Davis (1991, 1-10, esp. at 6-7). 
Does this mean that the opinions which Horace, and equally Vergil and Propertius, express through personae are therefore not authentic? Is a persona a performative medium which is used by the poet to heighten the poem's strength? The poet's choice of the performative medium is indeed important for the power and impact of representation. How should the poet write about or sing of the princeps, who after all controls the centre of power? How can it be done in a manner worthy of a responsible citizen? Is therefore the use of a persona a way of hiding? I suggest that the poets did not hide or submit themselves to authority or fear, or that their choices of poetic expression or genre were for the "performative effect" only, and that consequently the views expressed are a construct and not authentic. In the course of this study I will demonstrate that the poets persisted in many of their political opinions during many decades, and expressed these continuously over time and consistently over several genres. Often their views were critical of Octavian and later of Augustus and his policies, and they gave these views without prompting by a third party. It is unlikely that they would have done so if these opinions were not their genuine personal views.

Next, some characteristics of the visual media will be examined, beginning with the Republican era, followed by the years of the transition from the Republic to the Principate and finally during Augustus' reign. Examples in the public area such as statues, coins, reliefs and architecture, and, in the private space, such as mural paintings and ornamental pieces will be presented. The focus will be on characteristics such as the context of the creation and the nature of the images. This will be done in rather general terms and for detailed studies the reader is referred to the well-known standard works, such as Zanker's “The Power of Images in the Age of Augustus"31.

In the Late Republic one can find several examples of what Zanker (2010,1-25) calls "political imagery" on monuments, which in addition to visual images often carried texts as well. These generally revealed who had erected or repaired the monument and occasionally why. Many coins also carried political images, for instance the ten coins issued in 66 B.C. by Q. Pomponius Musa with Apollo on the obverse side and Hercules with the nine Muses on the reverse side. The latter is an obvious allusion to his name. Another form of allusion in the Republican age was the building of many temples for their patron deities by victorious generals; these contained many statues of the gods taken home as a loot from Greece or from the East. At the centre of these temples would stand a statue of the general himself bigger than those of the divinities.

Octavian was quick to learn from his predecessors. On 2 January 43, within a year of Caesar's murder and at the age of only nineteen, he was voted by the Senate a statue on the speaker's platform. Although the statue has been lost, we know of it because its picture was shown on a coin soon after. The equestrian statue was to stand next

31 See also: Galinsky, 1996, and Kleiner, 1992. For the relationship of Augustan poetry and visual representation see Barchiesi (2005, 281-305). 
to those of Sulla, Pompeius and Iulius Caesar, and so the object of the statue itself became an instrument of allusion: Octavian was as great a general as his illustrious predecessors. A second statue exemplifies this even stronger. Again, the statue is only known from coins, which were minted after Naulochus in 36 B.C.. Octavian was shown "in a pose familiar from late Classical Greek art. The model may have been a famous statue of Poseidon by Lysippus. The victor in a sea battle, he [Octavian] holds in his right hand the stern (aphlaston) of an enemy ship as a trophy, while the lance in his left hand marks him as a general. He rests his right foot on a sphaira, symbol of allembracing rule over land and sea” (Zanker, 2010, 39). This statue of Octavian was full of allusions to Sextus Pompeius, who was defeated in the final sea battle at Naulochus, after he had been victorious over Octavian at a number of earlier occasions ${ }^{32}$. Sextus claimed that he had been adopted by Neptune as a son, and thus Sextus used many maritime symbols, one of which was a statue - again known to us from a coin from 42-40 B.C. - where Sextus places his foot on the beak of a ship and which shows an allusion to pietas. This was clearly a sneer in the direction of Octavian which the latter paid back on the statue erected after his victory over Sextus at Naulochus; one could say that there was a "battle of allusions" between the two. In addition, Octavian may have referred to a second statue and this reference may be more important still. According to Cassius Dio (43.14.6), around the year 46 B.C. Iulius Caesar had erected a bronze statue with his foot placed on the globe, expressing power over the whole world. The "father" and the "divi filius" stood there for all to see.

Whether manifestations of "political images" in the public domain can be found on coins is a vexed question. Giving propaganda messages on coins differs from the use of coins for self-presentation and image building by the ruler (see also Hekster, 2009). Coinage was often used for the latter purpose. At least people should know that a ruler existed, who he was and what he looked like. At worst there was the desire for selfglorification by the ruler. For the purpose of this study, propaganda through coinage will be considered only briefly. Firstly, there are no indications that Octavian and later Augustus managed personally or through an intermediary the production of coins and their minting. His focus was on economic priorities, such as the money supply and not on the form (Levick, 1982, 104-116). Secondly, more than two hundred cities in the Roman Empire had a mint. In most cases there was no tradition to put portraits on the coins, let alone Roman portraits. However, Augustus appears regularly on coins, most likely on the initiative of the local authorities: this was probably to honour the emperor, or to use the auctoritas of Augustus as a means to facilitate acceptance and enhance the economic value of the coins. The portraits and symbols on the coins were

32 Powell (2004, 156). Octavian was defeated by Sextus in 42 B.C. in or near the strait of Messina, later near Sardinia, in 38 B.C. near Cumae and again in the strait of Messina and in 36 B.C. near Tauromenium. "The number of defeats inflicted on Octavian and his subordinates by the sea power of Sextus had enduring consequences for the reputation of Caesar's heir.” 
not the result of a message from Augustus, but rather an ingratiation or at best a sign of respect by the local elite ${ }^{33}$. This resulted in an informal interaction between Augustus and the designers of the coins, who gave their commentary on general moral themes (frugality, responsibility, trust, peace and stability) transmitted by Augustus: all this with a relatively great freedom.

The following issues of coins may serve as examples of this interpretation. Before 31 B.C. Octavian had issued a set of six denarii consisting of three pairs. Three coins carry the portraits of Octavian and on the reverse sides a picture of either Pax, Venus Genetrix or Victoria. The three other coins have the heads of the same divinities and on the reverse side a full-length portrait of Octavian either addressing his troops with an adlocutio, giving the signal to attack, or celebrating his triumph. The message is clear: Pax is the goal of the battle, Victoria is the result, and Venus is the protector of the admirable general. Apart from these six coins, there is also a series of three coins from the same period. Two of these commemorate the victory over Sextus and one shows the Curia. The latter symbolizes Octavian's promise to restore the Republic. Another example may be the so called Numa coins, issued in 3 B.C. These carry the head of Numa and are an allusion to the Pax Numana (that is the Pax Augusta). According to Galinsky (1996, 37):

Augustus' direct control over this highly unusual series of Numa bronzes can be safely ruled out [as the bronzes were produced by a young Piso ('who did not know to obey', TAC.Ann.2.46)]. His [Augustus'] actions suggested the broad themes; in this case the revival of old religion, the reestablishment of peace and Republican traditions, and the importance of a new saeculum. These were expressed, elaborated and extended by individuals in their own way.

Galinsky $(1996,39)$ summarises the function of coins in Augustus' time as follows: "At most coin types can serve as a reflection on, and as a record and affirmation of, something that is already known through other sources. Conversely, some of Augustus' major programs, such as the legislation on morals and marriage, found no expression in his coinage."

The third type of public images, that of reliefs, and in particular those of the temple of Apollo on the Palatine and those found on the Ara Pacis Augustae, is important. Octavian had promised Apollo a temple after the defeat of Sextus in 36 B.C. and it is estimated that the temple was dedicated in 28 B.C.. Some terracotta plaques of the temple have been recovered and one shows the battle of Apollo and Hercules for the Delphic tripod. Some authors see in this an allusion to the struggle for hegemony between Octavian and Antony. Another interesting political image, the death of Niobe's children, was shown in a prominent place on the temple doors. According to Kleiner (1992, 84): "In sum, it is apparent from scholarly interpretation of the

33 Burnett, Amandry, \& Ripollès, et al. (1994, 593-594); Levick (1982, 107). 
sculptural program of the Temple of Apollo Palatinus that it was carefully orchestrated by Octavian, in concert with a master designer, to underscore his personal rapport with the god Apollo, and to make reference to his momentous victory over Antony and Cleopatra at Actium" (see also Kleiner, 2005a, 220-221). Octavian's temple for Apollo competed with the rebuilding of the temple for Apollo in Circo by C. Sosius, who had fought on Antony's side, but had been pardoned. But Sosius understood the new political realities: a frieze of the rebuilt temple showed Octavian's triple triumph and not Sosius' own triumph ex Judaea in 34 B.C.. His newly-found loyalty went even further when he placed an Amazonomachy in the pediment of the temple. This was generally seen as referring to Octavian's victory at Actium, which was often compared with the defeat of the Amazons by the Athenians (Zanker, 2010, 84-85).

The Ara Pacis Augustae, which was built by order of the Senate between 13 and 9 B.C. is the apex of political references. The "Altar of Augustan Peace" had been voted to the princeps as a monument to peace after his safe return in 13 B.C. from Gallic and Spanish campaigns. Of interest here are the reliefs that tell the history of Rome and the emerging new dynasty. History was represented by a panel on the front of the building, on the west side; to the right of the entrance Aeneas together with Ascanius is seen sacrificing after their safe arrival in Latium. Aeneas is shown as a ruler with a spear and in Roman dress, whereas Ascanius is represented as a youth still in Trojan dress and holding a shepherd's staff. Immediately around the corner of Aeneas' panel, we find Augustus together with the young Gaius and Lucius, Augustus' adopted sons, also in Trojan dress. In this way Augustus was linked to Aeneas and the boys Gaius and Lucius to Ascanius. The scene referred to Augustus' "descent" from Aeneas and to the continuation of this historic line in Gaius and Lucius. More mythological figures were placed on the east side of the monument, the goddess Roma sitting on a pile of discarded armour and what is most probably Pax with all kinds of fertility symbols. The message is clear and Zanker $(2010,175)$ summarises this as showing "that the blessings of peace had been won and made secure by the newly fortified virtus of Roman arms."34

The north side of the altar depicts a procession of senators and families. This is repeated on the south side with the addition of the extended imperial family, including children, led by Augustus in his office of pontifex, who, together with a group of priests, performs the rites and sacrifices to the household gods. The two processions were presumably intended to be seen as one. These two friezes represented a powerful political message. Firstly, the pride of place was given to Augustus and the family, symbolising the elevated position of the emerging dynasty, while the Senate is to be found at the tail end of the procession. Secondly, the coming together of Aeneas

34 There are various identifications of the goddess: Tellus, Venus, Italia, Ceres or Pax. Zanker considers Pax the most likely as the monument is the Ara Pacis and the neighbour panel is that of Roma with the discarded armour. 
and Augustus symbolised not only Augustus' divine descent, but also his task of establishing a new order and restoring peace, as Aeneas had done before him ${ }^{35}$.

The political images just mentioned were very much in the public space and I will now turn briefly to some of those in the private domain. Antony's identification with Dionysus was an easy target for political attacks. Supporters of Octavian used it to denounce Antony as a man whom Cleopatra held in her evil clutches. Their Alexandrian parties were portrayed as foreign and decadent orgies typical of the East, and all over Rome effeminate statues of Dionysus - for instance in private gardens were given Antony's features. As a protégé of Apollo, on the other hand, Octavian was perceived as a paradigm of order and good morals and many owners of great houses set up portraits of Augustus and his family.

Several examples of scorn for Antony can be found. The same mockery which had been used against Pericles centuries earlier was now used against Antony, as several clay bowls produced in a pottery in Arezzo show. In one of them, Heracles, dressed as a woman, sits in a chariot drawn by centaurs and Omphale follows in his lion skin in a second chariot. Heracles looks longingly back at Omphale. At the same time, he is well looked after by servant girls while she is offered a large drinking cup. The allusion is clear: the spear-carrying guards behind the second chariot and the large drinking cup were seen as referring to Cleopatra, and the effeminate Heracles is obviously Antony ${ }^{36}$. Hekster $(2004,164)$ offered the interesting view that "without any direct evidence that the figures on display refer to Mark Antony and Cleopatra, and without any evidence that the design originated from Augustus or the circle surrounding him, it becomes hazardous to use the motif on the pottery as evidence for a grand Augustan [propaganda] programme." I share his opinion that this and other images of Heracles and Omphale were not part of Augustan propaganda - if that existed at all - but I differ from him when he testifies in the summary of his article that "it seems that a political reading of the images is stretching the evidence too far." These kinds of images in the visual media or words in literature may never have been meant to refer to a topical political issue, but may have become symbols of what discerning and educated Romans were very apt at interpreting as allusions to contemporaneous political events. It is not only in the Arezzo pottery that the Omphale-Cleopatra connection appears, but also in the poetry of Vergil, Horace and Propertius. A particular case in point is PROP.3.11, probably written in 24 B.C.. In the elegy, Omphale joins other (mythical) women, who represent the (evil) female powers of oriental women with ambitions to dominate the world, a well-known theme in Rome. The poem concerns the threat of Cleopatra, the decadence of the queen and of Egypt in general, the battle of Actium and the events which followed, and above all

35 For the Ara Pacis see Galinsky (1996, $106-109$ and 141-150); Kleiner (1992, 90-99; 2005a, 212-217 and 221- 225); Zanker, 2010.

36 Zanker (2010, 59-60). Plutarch referred to this in Demetrius and Antony 3.3. 
the contrast between Antony's enslavement and Octavian's sense of duty. It is unlikely that the poem was propagandist as it was written so many years after the events, when the threat from Alexandria had long been removed. PROP.3.11 is an example of allusions to similar feelings as are expressed in the Arezzo Hercules-Omphale bowl: feelings which were presumably widely felt and which could be recognised in the visual media and in literature by the Roman cultural and social elite. Of course the elegy has also a second (non-political) theme: one should not wonder that a woman (Cynthia) governs Propertius' life when one sees that so many great heroes and men were dominated by women.

At home, in a private villa, a patrician - or a parvenu - could explain the scene to his guests and show them where he stood. To quote Zanker $(2010,62)$ :

Mythological symbols and parallels also offered contemporary Romans the chance to express their affinity with one side and its lifestyle or the other. It is becoming increasingly clear that the political affiliations that can be detected in poetry are intimately related to those expressed in the visual arts, even in the private sphere, as in the decorative scheme of a room or in such diverse objects as tableware and seal rings.

Finally, this section will be closed with a fine example of political imagery in the private sphere, namely in the decorations of a room, the use of wall paintings. In Boscotrecase, near Pompeii, Agrippa's family owned a large estate with a beautifully decorated villa. In one of the rooms, a wall painting in the Third Style has been discovered, probably dating from 10 B.C.. The scene is a pastoral idyll, a bucolic fantasy in the words of Zanker (2010, 285), which was not uncommon at the time (Zanker, 2010, 283-287). The painting displays a sacrifice before an enthroned goddess in an idealised pastoral landscape where no toiling farmer is visible. The landscape is a park with some trees dominated by a temple and a villa. The pastoral element is a herdsman with his goats. The picture exudes the happiness of life in the countryside when one has escaped from the moral decay of the city. The image is much in vogue as mythical elements are absent in this picture. Yet, the painting gives a powerful political message in support of Augustus, which was to be expected in a villa of this family. It alludes to a peaceful and tranquil life in the countryside which can be found now that order and peace have been restored by Augustus. It is possible to escape the bustle of the city where the princeps is at work establishing his empire and managing the affairs of state.

To summarise, different forms of visual images proliferated both in the public and in the private areas. Through these the patrons of the arts wanted to express their views or to broadcast their political messages in public spaces and their wealth and allegiances in private spaces. This was achieved by a subtle artistic representation of well-known figures or events from the mythical or historical past, which either alluded to the patron's successful behaviour in contemporaneous events or showed the patron or his policies in the most flattering light. In principle, this was not different from the situation in the last decades of the Republic; it was only the scale which differed. The princeps was a major patron and many manifestations of his political 
image are known. "Reading” references and allusions in the visual media was not all that different from reading those in poetry.

\subsection{Literacy And Audience For Poetry}

At the time of Vergil both in poetry and in the visual arts references to contemporary issues were not uncommon. In subsequent chapters I will show several examples of those in Vergil's poetry, making up part of the political messages he sent out in both the public and in the private spheres. But before conclusions about the impact of political poetry can be drawn, two different issues must be considered first. These are the questions of the ability to read Latin poetry in different social strata of Rome and Italia in the first century B.C., and the related one of the audiences of poetry. The point is of course that impact of poetry was dependent on the size and type of its audience. A situation where hardly anyone was able to read poetry, or where poems were only read by or recited to certain groups, would have been very different from one where poetry enjoyed a wide and socially diverse audience.

The question of literacy is fraught with difficulties. There has been much scholarly research on this matter, which has been summarized by W.V. Harris ${ }^{37}$. Before discussing literacy a few points need attention. Firstly, confusion can arise about the use of the word literate, which can mean two things: either "cultured" or "capable of reading and writing." I am concerned with the latter meaning. Most likely there was a great difference between reading and writing levels in Rome. In this book, the focus will be on reading for the reception of Latin poetry by contemporaries. Secondly, in antiquity, literacy differed greatly between men and women; there were only a few women of the upper classes who could read and write. Thirdly, and most importantly, the definition of literacy is very unclear. This makes the results of the many studies of the historical development of literacy and the recent official surveys by UNESCO or others unreliable $\mathrm{e}^{38}$. The figures which will be given in this part are therefore estimates with a wide range of uncertainty. Fourthly, in view of these uncertainties, Harris (1991, 3-8) suggests to divide people into three groups according to their reading and writing ability: a first group of illiterates, a second of literates and a third middle group

37 Harris, 1991; the following chapters are of particular interest: I. Introduction: Levels of Greek and Roman Literacy; II. Introduction: The Functions of Literacy in the Graeco-Roman World, and VII. Literacy and Illiteracy in the Roman World: The Late Republic and the High Empire, 100 B.C.-250 A.D.

38 Harris (1991, 3-8). In Harris' opinion the definition of UNESCO is the most acceptable. This definition is: "an illiterate should be defined as someone 'who cannot with understanding both read and write a short simple statement on his everyday life."” The problem however is that this definition is not respected by many officials in several countries. Harris is sceptical about the measurement of literacy by the use of people's ability to sign for instance a marriage certificate or by counting the number of years of some form of elementary schooling. 
of what he $(1991,5)$ calls semi-literates, who are the "persons who can write slowly or not at all, and who can read without being able to read complex or very lengthy texts." This third group of semi-literates belongs, for the purpose of this study, to the group of illiterates, as poems are generally complex or very lengthy texts.

In our Western, industrialised world the ability to read and write is generally seen as something natural. However, "in rural Greece in 1951 the illiteracy rate among males was $14.9 \%$, that among females $49.9 \%$. Greece at the time, however, was a country in rapid transition; more typical of an early-modern setting would be Sicily in 1871, with $79 \%$ male and $91 \%$ female illiteracy." ${ }^{39}$ Societies can only achieve mass literacy when some preconditions have been fulfilled, such as the cheap mass production of reading material, schooling on a large scale, and economic necessity. The cheap mass production of reading material only started after the introduction of the printing press in the fifteenth century and an extensive school system was not in place before the nineteenth century. For instance, during the period of the industrial revolution, in eighteenth-century England, the literacy rate of the male population shot up when the factory owners started to want a literate workforce. Another impulse for the growth of literacy can be religious or ideological in nature, such was the case of the increase in Protestant Germany and Holland in the sixteenth and seventeenth centuries when people wanted to read the Bible at home.

It is clear that none of these preconditions existed in Rome in the first century B.C.. Although there were competent copyists and there existed a level of trade in books, there was nothing like mass production, and the costs of the raw materials were such that only the rich could afford to buy books. A school system as such existed only on a limited scale and presumably only in the cities. The education in the privately run "primary" schools was only for boys whose parents could afford the fees. Here they were taught reading, writing and some arithmetic. "Secondary" education was given by a grammaticus who taught Latin and Greek grammar through the reading of the great classical writers. Yet, it is unlikely that the writers who are the subject of my study were read in schools in the last decades of the first century B.C.. Horace was outspoken about the subject. In his literary Satire (S.1.10), probably written in the year 35 B.C., he writes about his own expectations as a poet. In the lines 74-76 he says: an tua demens/vilibus in ludis dictari carmina malis?/non ego (What, would you be a fool, wanting your poems dictated in common schools? Not for me). And in 21 B.C. he reflected on the fate of his poems by writing in Ep.1.20, 17-18 (the final lines of his first book of Epistulae): hoc quoque te manet, ut pueros elementa docentem/occupet extremis in vicis balba senectus. (This awaits you too, that stuttering old age takes possession of you as you teach boys their basics in the city's outskirts). Horace was scornful about a future for his poetry as teaching material, and he rather saw himself

39 Professionals in orthopedagogy in The Hague estimated in 2008 that the illiteracy rate of children in their later years of primary education living in certain deprived areas is in the order of $20 \%$. 
as me primis Vrbis belli placuisse domique (that I was welcome, in war and at home, with the most excellent in the State) (Ep.1.20.23). Eventually, he was unable to prevent the use of his poetry in schools, but it appears that he did not encourage it and perhaps it took until after his death in 8 B.C. before it was part of the curriculum.

Remnants of school buildings have hardly been found. Generally teaching took place in makeshift classrooms, outdoors, at the corner of the forum or on the street. Boys and girls of the upper classes and of the new rich were often educated within the family walls by itinerant teachers, often learned slaves. Boys learned to read and write and were prepared for the typical elite forms of "higher" education in rhetoric and law, again at home (Harris, 1991, 233-248).

Two driving forces in Roman society had a positive effect on the literacy rates, the army and international trade. Both the army and international trade required the services of a considerable number of literates, but the effects on general literacy were limited. Harris (1991, 18-19) states rightly:

We must distinguish between, on the one hand, an economy [like the Roman one] which provides a certain number of clerical jobs and gives some incentives, though not an overwhelming one, to an artisan or shopkeeper to read and write, and, on the other hand, an economy [like ours] in which the mass literacy of its workers and its consumers is an integral feature. It is obvious that the Romans never went beyond the former of these situations.

Establishing literacy rates in the Augustan age has given rise to much conjecture, and in general high estimates of literacy rates in Roman society prevailed before $1970^{40}$. Harris $(1991,9)$ quotes Guillemin $(1937,77)$, "that there were few illiterates in Roman antiquity, 'even among slaves,” and Harris (1991, 14) quotes Marichal (1963, 208) who testified that “many Romans read newspapers.” It is Harris' $(1991,22)$ view that "the likely overall illiteracy level of the Roman Empire under the principate is almost certain to have been above $90 \%$.” This refers to the overall level. In much of the empire, including Italia, the written word was never encountered. However, the written word had spread considerably within the administration, the army and international trade. There were many specialist literates in these areas due to the increased need for written documents such as wills and marriage contracts, as well as due to the requirements of the management of the state and of the army in documents such as tax and property records and rosters of army personnel. Anyone who wanted to draw up a contract or record a transaction could use the professional services of these specialist scribes, often slaves, who would write up the document. Transactions of a

40 Harris estimates much lower literacy rates than other scholars. I give two quotes out of many. Harris (1991, 270) discusses rates in Roman Britain: "Unawareness of ancient educational conditions, tinged perhaps by patriotic optimism, has allowed some exaggerations,” and Harris (1991, 280) mentions that the costs of education prohibited many to learn to read and write " - which would hardly need saying but for persistent lack of realism on this subject among scholars.” (my emphasis). 
modest size, however, were seldom put in writing. Apart from the corps of specialist scribes, one encountered a high degree of literacy with the legionaries, while the auxiliaries were in the main illiterate. Officers in both armies could read and write ${ }^{41}$.

Much official communication with the public at large was not written but oral, for instance through town criers, the praecones. They announced public meetings and voting results, and gave general information. As a rule, official decrees and edicts were posted at public places such as the forum for anyone to read and if one could not read there was generally someone who could read it aloud.

The writing of letters was very common, not only in the private domain. The communication between Rome and the governors in the provinces or between the provincial administrative centres and the commanders of the army was generally by letter, which had the advantage that it could overcome distance. The same held for communication with and between traders in the provinces.

The overall literacy level of $10 \%$ then, will almost certainly have included a very high literacy level among the educated elite who wrote and read Greek and Latin literature, studied philosophy, wrote letters, prepared and made legal pleas, addressed political meetings and so forth. The aristocracy and the new rich constituted the elite, and the senators and higher officials were recruited from this class. Examples from the Augustan age are C. Asinius Pollio and C. Cornelius Gallus, both literary men prominent in public life. Contrary to the standards of today's prosperous Western world and of parts of the Eastern world with its increasing prosperity, the Roman Empire as a whole had a relatively small middle-class of, among others, successful freedmen, professionals and officials, craftsmen and middle-ranking army personnel. This was also true for Rome and Italia. Within this class there was a fair degree of at least the ability to read. The group of people who were poor or very poor was much larger than it is commonly believed. Needless to say that the widespread poverty meant that many children - boys - remained illiterate; not dissimilar to some of the poorest countries we know today.

Thus far the level of literacy in the Roman Empire at the end of the first century B.C. has been considered. What matters for our subject is not just literacy as such, but more specifically the ability to read Latin, as the poetry of Vergil, Horace and other poets was not translated into other languages at the time. This raises the questions

41 Harris (1991, 253, note 413). Harris gives an amusing anecdote which shows that the army in general had a rather high degree of literacy. There were attempts in the late 40s and 30s B.C. to propagandise the soldiery. I quote Harris: "In 46 Caesar tried to subvert both the local and Roman troops of Scipio Nasica in Africa by means of brief biblia, with some success; Nasica replied in kind (Dio xliii.5; cf. Bell. Afr. 32). Octavian tried the same technique on Antony's army in 44 (App. BC iii.44: many biblia), as the Caesarians did against Brutus before the second battle of Philippi (Dio xlvii.48.1). When Antony had such leaflets shot into Octavian's camp outside Alexandria in 30 B.C. (which, incidentally, shows what a lightweight object a biblion could be), Octavian read them out to the soldiers himself (Dio li.10.2-3)." So much for written propaganda. 
of Latinisation and bilingualism: for the purpose of this study I define the latter as the ability to speak and read Latin, next to the ability to speak, read and possibly write another, generally indigenous, language. In a large geographical area as the Roman Empire many local and generally very old and long-established languages of old civilisations existed. The situation differed greatly between Rome and some other large cities in Italia and the countryside, for instance in southern Italia. As an aside, this was also the case in Rome itself with her many immigrants and a large imported population and the resulting great social differences. The Latinisation in many Gallic and Spanish cities was much more advanced than in Alexandria and other cities of Hellenistic origin, where Greek was the language of the upper classes and the administration, and education was seen as natural. During the reign of Augustus' successor Tiberius (14-37 A.D.) - admittedly a few decades later than the period which I discuss - a boarding school for sons of the aristocracy in Gallia was established in Augustodunum (modern Autun). In the backwoods of, say, Cappadocia or Cantabria literacy was virtually zero, Latinisation was minimal and bilingualism hardly existed. In general, the presence of the army was an important factor ${ }^{42}$.

In summary, it is not possible to come to precise figures of the ability to read Latin in either Rome and the other towns of Italia, or the Italian countryside, or the different cities and regions of the empire in the Augustan age or to specify these for the different social strata of Roman society. However, two general conclusions may be drawn. Firstly, with respect to the overall levels of literacy, Harris gives the following estimates for the various regions. In Rome and Italia the overall level of literacy was below $15 \%$, and he gives a similar figure, for instance, for Gallia Narbonensis and Baetica (modern Andalusia and Granada) and for the cities in the African provinces of Numidia (modern Northern Algeria) and Africa (region of Carthage; modern Tunisia). Harris estimates the average literacy level for the Western provinces as a whole as between 5 and 10\%. In Rome and Italia literacy is defined as the ability to read and write Latin and in the Western and African provinces as being bilingual according to the definition given above. However, the situation in the Eastern provinces is very different as the main language for literates was Greek. Thus, an estimate that the overall level of literacy in the latter provinces was similar to Rome and Italia does not mean that the ability to read and write Latin was similar as well. Secondly, considering the literacy in different social strata, Harris states that the social and intellectual elite of Rome and the larger towns of Italia could generally read and write, often both in Latin and in Greek, although there were still many members of the upper classes who were illiterate. An appreciable part of the successful freedmen, craftsmen and traders of these cities could read Latin. Since the Roman elite spent much time on their estates in different parts of Italia, small pockets of Roman culture came into being there. In the provinces however, the great majority of people was not latinised and did not

42 Harris (1991, 175-193). In these pages, Harris discusses all geographical areas of the Empire. 
participate in the Latin cultural manifestations. There were pockets of acculturisation in the towns where groups of originally Roman administrators, traders and others mixed with the indigenous populations, who together formed the elite and who could read and write Latin. This was a small minority and constituted a much smaller percentage of the total population than in Rome $^{43}$.

Who were the audiences of poetry and how much were they in touch with poetry? Did they read poetry or did they listen to public or private recitations? Did people purchase books? Was Latin poetry read in places outside Rome, in Italia or perhaps far away in the provinces? Horace referred to this latter question in his Ep.1.20 and his Carm.2.20. In the former he reflected on the fate of his poems and in Ep.1.20.10-13 he says to his book:

carus eris Romae, donec te deserat aetas;

contrectatus ubi manibus sordescere vulgi

coeperis, aut tineas pasces taciturnus inertis,

aut fugies Vticam aut vinctus mitteris Ilerdam.

(you will be precious in Rome, till your youth deserts you; when you've been touched by vulgar hands and begin to grow filthy, you will either in silence feed artless bookworms, or will run away to Utica, or be sent in chains to Ilerda)

Horace was proud of his success in Rome, but feared that this might change and that his book of poems might be disregarded and would turn up in Utica, North Africa or Ilerda (modern Lerida) in Spain: just like a master who sells off his ageing slave. A few years earlier, in 25 B.C., he had finished his second book of Odes and in Carm. 2.20 he referred to his hope that after his death his work might survive and that he would visit the outermost borders of the known lands as a canorus ales ('a tuneful swan'). In the two passages Horace did not necessarily refer to an international readership; his words express, in the Epistula (donec te deserat aetas) the fear of future obscurity, and in the Ode, the hope of future fame. In line 13 of the latter he compared himself to another famous flyer Daedaleo Icaro (Daedalus' Icarus) and wished to become notior (more renowned) than him (Icarus). Nisbet and Hubbard's (2004, 337) commentary on this line is: "in choosing bizarre symbols to express his thought, he [Horace] shows an agreeable detachment from a deeply felt aspiration."

Before discussing the audiences of poetry, the process of the making and distribution of books will be first considered. How did a book of poetry come about? Was it published and then sold through the book trade? Was there a market for books?

According to Starr $(1987,213-223)$ not much is known about the book trade in Vergil's age. Perhaps this lack of knowledge is not all that serious as we have a fair idea about what Starr calls "book circulation." He $(1987,213)$ states that "Romans

43 Harris (1991, 259-282); MacMullen (2004, 215-231); Woolf (2004, 231-242). 
circulated texts in a series of widening concentric circles determined primarily by friendship, which might, of course, be influenced by literary interests, and by the forces of social status that regulated friendship." Starr offers a credible model suggesting that an author sent gift copies of the finished work to his circle of friends and that this was effectively the point of release of the book, and after that it was openly accessible. The author had these copies made at his own costs and under his own management, and there was no commercial copying at this stage. When the text had been released, other people were free to make their own copies. There were no commercial transactions, and if someone wanted a copy made they had to pay for the creation of a copy, with no copyrights payment to the author. Most readers depended largely if not entirely on privately made copies, not only for new, but also for older work.

Libraries formed another source from which work could be obtained for copying. A number of private libraries existed in the Roman townhouses and country villas of the upper classes. It is generally held that L. Aemilius Paullus Macedonicus was the first to bring books to Rome, those of king Perseus after the take of Pydna in 168 B.C.. Faustus, the son of Sulla, continued his father's library after his return from Athens in 86 B.C.. This library contained a considerable part of Aristotle's private collection. Lucullus created a private library in Rome and Tusculum which was stocked with books he had brought back from Asia Minor. These libraries lost parts, or perhaps the whole of their collections through confiscations in the late 40 s or early 30s B.C.. A wellknown library outside Rome is that of Piso, which was found in Herculaneum. Others like Cicero and his friend Atticus held large collections of books. Cicero mentions in his letters that he consulted the libraries of his friends and that he borrowed books to have them copied $^{44}$.

Apart from private libraries, some public libraries were also established in Rome. The first one was the library which Iulius Caesar had planned, but which was built by Asinius Pollio in the Atrium Libertatis in the late 30 s or early 20s B.C., quickly followed by two libraries by Augustus, one next to the temple of Apollo on the Palatine in 28 B.C and one in the Porticus Octaviae which was built after 23 B.C. ${ }^{45}$. Public libraries

44 Casson (2001, 61-108). Cicero wrote about the library of Lucullus in Fin. 3.2.7: Nam in Tusculano cum essem vellemque e bibliotheca pueri Luculli quibusdam libris uti (for when I was down at Tusculum, and wanted to consult some books from the library of the young Lucullus); about the library of Sulla in Att.4.10.1: Ego hic pascor bibliotheca Fausti (I am nourished here by Faustus' [Faustus Sulla's] library) About borrowing books from Atticus he wrote in Att. 8.11.7; 8.12.6; 13.31 .2 and 13.32.2. Some examples are: Att.13.31.2: Quoniam etiamnum abes, Dicaearchi quos scribis libros sane velim mi mit-

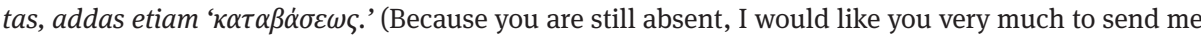
Dicaearchus' books of which you write, and add also his 'Descent'.') and in Att.13.32.2 he repeats his

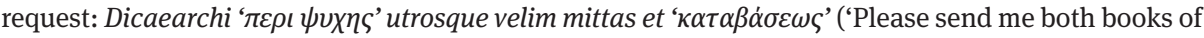
Dicaearchus 'On the Soul,' and the 'Descent.'). See also Quinn (1982, 125-128).

45 Horace referred to this library in his Epistula ad Augustum (Ep. 2.1.216-217). Although there were libraries in Rome, Gallia for instance did not have a single library at the end of the first century B.C. 
held contemporaneous authors, as a passage from Ovid's Tristia shows. When Ovid was banished in 8 A.D., his books were forbidden and their author was no longer able to visit the library on the Palatine. About this library Ovid says in Tr.3.1.63-64: quaeque viri docto veteres cepere novique/pectore, lecturis inspicienda patent (all those things which men of old and of today have come to in their learned minds are open for inspection by readers).

Distribution of copies from a master copy held in a public library cannot have started earlier than about 30 B.C., when Vergil had finished his Eclogues and Horace his Satires and Epodes. In 30 B.C. only the public library of Pollio had been opened and therefore the supposed dissemination of propagandist literature at the time before Actium and the fall of Alexandria was not possible through these channels.

Book dealers were a third option. It is assumed that they stocked older works and a limited selection of recent work. Normally, the book dealer made only the copies he sold, a kind of copying on demand. In Cicero's time there were some booksellers at Rome whose copies were often of a dubious quality. Cicero complained about this poor quality in one of his letters to his brother Quintus (Q.fr.3.6.1), where he writes: de Latinis vero quo me vertam nescio; ita mendose et scribuntur et veneunt. (Regarding Latin books, I don't know where to turn; the copies are written and sold full of faults). Horace referred in Ep.1.20.1-2 to the possible sale of his book in a bookshop. He says:

VERTVMNVM Ianumque, liber, spectare videris, scilicet ut prostes Sosiorum pumice mundus.

(Toward Vertumnus and Ianus, my book, you seem to look, in order, of course, that you may be offered for sale, polished smartly with Sosii’s pumice)

The Vortumnus was a well-known shopping street in Rome with some book trade and the Sosii were booksellers. When Horace wrote these lines in 21 B.C., he reckoned with the possibility that a number of copies of his book would be distributed through the book trade. However, he had his reservations about that option. He used indeed words related to young male prostitution, such as prostes and pumex (pumice); the latter was used by boys for scraping off their bodily hair in order to look younger, but also for smoothing the ends of the book rolls. Horace referred to the Sosii again in his Ars Poetica (Ars.344-346), when he wrote about "international best sellers". I interpret these lines not only as a description of the bookseller's work but also as a reference to his own desire to keep away from the cheap writing for the masses. He implies that there is nothing wrong with a poem that both delights and instructs, but it should not be judged on those criteria alone. There ought to be a place for other poetry as well. Horace seems to suggest in these lines that only poems which were expected to do well commercially were selected by booksellers. The lines say: 
lectorem delectando pariterque monendo;

hic meret aera liber Sosiis; hic et mare transit

et longum noto scriptori prorogat aevum.

(Delighting and equally instructing a reader; such a book earns the Sosii money; this crosses the sea and preserves for a long time its author's name)

It is obvious that this system of dissemination of literary work could not create a great number of copies. It was expensive and out of most people's reach, and one had to find a "master copy" to be able to make a duplicate. Thus, obtaining a literary work was a matter of a specific search. Any form of advertising and hard selling was completely absent, and thus one needed to have active knowledge of, or at least interest in, the work of the author. One could gain this knowledge from friends, hearsay or private and public recitations. In many cases the acquaintance of and affinity with the work was the result of contacts within a limited circle with shared interests and ideas. Therefore, it seems probable that most copies of, for instance, the poetry of Vergil or Horace were read or recited within a limited group of people, generally men, who shared the poet's culture and education, and who could discuss the ideas expressed by the poets. Moreover, as I will discuss below in the section about patronage, most poets belonged to the upper class. Starr $(1987,223)$ makes the point that

for older Roman writers [for instance Vergil and Horace], literature was always seen as merely one facet of the life of an aristocrat, albeit a very important one. Although writing and reading undoubtedly affected their social relationships, those relationships were also based on other ties such as politics, marriage alliances, and family traditions.

Above I have touched only lightly on the question of which people or groups formed a poet's audience, the final stage in the process of transmitting his (political) views or feelings ${ }^{46}$. If poetry was being used for propagandist purposes, the question whose minds were targeted - the public at large, the soldiers, the middle class, the upper class, the senate or all these groups at once - should be addressed. According to Quinn (1979, 35; see also 1982, 140-165) literature in Roman society reveals a fundamental dichotomy:

On the one hand, there is the possibility of a large audience, the possibility of a viable social function; if the writer is appreciated, he can feel he is worth his salt. On the other hand, there is the likelihood of no more than a small hypercritical élite more interested in technique than in what the writer has to say and the frustrating feeling of fulfilling no social function.[...]. The conflict is occasioned in large measure by the shift from an oral literature to a written literature: Plautus had a wide audience, for whom he had an immediate appeal; Horace wrote for a small audience of those seriously interested in difficult poetry.

46 Goold (1992, 110-123); Quinn, 1979; Quinn (1982, 75-180); Woodman \& Powell (1992, 204-215). 
Plautus' audience, made up of craftsmen and soldiers or ex-soldiers, could not read well enough to appreciate a long and difficult text, and they relied only on oral transmission. However, it is not Plautus' time we are interested in, but the last decades of the first century B.C.. At that time only a few tragedies and comedies of consequence seem to have been written, and drama did not hold a similar position in Roman life as it had done in previous centuries. According to Quinn $(1979,92)$ mime, comparable to our "music-hall shows ranging from striptease to political satire", became fashionable and was the entertainment for the general public ${ }^{47}$. The writers of drama were members of the upper class who did not write for the stage and did not want to be associated with organized performances (Quinn, 1979, 113; White, 1993, 47-63). Pliny the Younger (Ep.6.21) wrote about the reading of a comedy to a select few (paucis) by Vergilius Romanus in a letter to his friend Caninius Rufus ${ }^{48}$. Although Pliny wrote in the first century A.D., he described a custom which had started a hundred years earlier. Ovid's Medea was presumably never performed on stage, "since later in life Ovid boasted he had never written for the stage." (Quinn, 1979, 113). The same holds presumably for the tragedies of Asinius Pollio. Large audiences could also be reached through performances in which the poems were sung. Lowrie $(2009,83-97)$ examines this thoroughly for the case of Horace's Odes. She notes, however, that it is not clear whether sung performances actually took place, even taking into account Horace's own references to music. She (Lowrie 2009, 83) states: "we cannot determine whether Horace's self-referential musical vocabulary is figurative or literal," although in her opinion this does not exclude "their historical performances." Yet, it remains uncertain if, in the case of poems being sung, large popular audiences were reached.

Unlike the writers of comedy, Vergil and Horace - writers of serious poetry -had to find a new position for themselves and their poetry. They had no contacts at all with

47 Horsfall (2003, 15; 56); Quinn (1982, 152-158). Lowrie (2009, 83) states: “Vergil's Eclogues were performed as mime." Three ancient texts refer to theatre performances of the Eclogues. The first is found in Vita Donati.26 (Hardie, 1966, 8): Bucolica eo successu edidit, ut in scena quoque per cantores crebro pronuntiarentur (He produced the Bucolica with such a success, that these were also frequently performed on stage by singing actors). The second is in Servius' commentary on Ecl.6.11 (Thilo, 1887, 66): [...] hanc eclogam constat in honorem Vari esse praescriptam. dicitur autem ingenti favore a Vergilio esse recitata, adeo ut, cum eam postea Cytheris meretrix cantasset in theatro, quam in fine Lycoridem vocat, stupefactus Cicero, cuius esset, requireret. (it is certain that this eclogue was written in honour of Varus. It is said however, that the poem was recited by Vergil under very great applause, so much so that, when later the prostitute Cytheris, who eventually was called Lycoris, declaimed it in the theatre, a stupefied Cicero demanded to know whose it was). "Cytheris was the most famous mima." (Quinn, 1982, 156). We will meet Cytheris/Lycoris again later in relation to Cornelius Gallus. The third text is from St. Augustine who writes of Vergil; “'few of you have known him from the text, many, from theatres”; that could mean, either from public readings or from dramatic performances' (Horsfall, 2003, 15). It is known that public readings of the Aeneid continued until the seventh century A.D., but this does not prove that it was widespread in the first century B.C..

48 Not much is known about Vergilius Romanus; this mention in Pliny's letter is the only source. 
popular audiences: the contacts within their circles of amici helped them to find new audiences.

Private readings of plays and poems to invited audiences and solitary reading became fashionable with the elite, who looked down on popular theatre. Readings to small groups were social as much as literary events (Quinn, 1982, 140-145). Servius testifies to this in his commentary on A.4.323: cui me moribundam deseris, hospes? (To whose mercy do you abandon me, who will soon die, guest?), the lines which Dido spoke when Aeneas deserted her. Servius writes that, when the passage was read to Augustus cum privatim paucis praesentibus (at his home with a few people present), the princeps was greatly affected. Such recitations were generally held among groups of social and intellectual equals, and this could certainly lead to social interaction, for instance by commenting on the texts.

Lowrie $(2009,14)$ testifies: "It is generally agreed that elite, literary reading was a kind of performance rather than the solitary activity now standard, although there has been something of a backlash against a purely oral understanding of reading: silent and solitary reading did exist and was presumably common among the welleducated.” She (Lowrie 2009, 52) states also: “scholarship in antiquity did not occur in a social vacuum. [...], much research entailed social interaction, whether the company of a slave, a friend, or a group of peers, in person or by correspondence. Cicero and his friends circulated and discussed texts. Even solitary reading is a social practice.”

It is well known that Vergil read his work in private sessions (Goold, 1992, 110-112; White, 2005, 322-323). Some testify that he was shy and soft-spoken. In Vita Donati.16 we read that Melissus, Maecenas' freedman, said: in sermone tardissimum ac paene indocto similem (speaking very slowly and almost like an uneducated man ${ }^{49}$. More evidence can be found in an episode reported in the Vita Donati referring to an occurrence after the battle of Actium. In the Vita Donati.27 we read:

Georgica reverso post Actiacam victoriam Augusto atque Atellae reficiendarum faucium causa commoranti per continuum quadriduum legit, suscipiente Maecenate legendi vicem, quotiens interpellaretur ipse vocis offensione.

(He [Vergil] read the Georgics to Augustus during four successive days when he returned after his victory at Actium and stopped at Atella for curing his throat, and Maecenas took his turn at reading as often as he [Vergil] had to stop speaking by the loss of his voice).

Another mention of private readings by Vergil to Augustus is in Servius' commentary on A.6.861, where he notes that Vergil read book 6 to Augustus and Octavia, and probably others as well. One of the listeners, perhaps Octavia, broke out fletu nimio (in excessive weeping).

Horace has testified which kind of audiences he preferred. In S.1.10.73-74, which he probably wrote in the year 35 B.C., he says that he does not attempt to reach large

49 The texts from the Vita Donati is in: Hardie $(1966,5 ; 8)$. 
audiences: neque te ut miretur turba labores,/contentus paucis lectoribus (and that you should not strive to be admired by the crowd, but that you be content with the select few as your readers). Horace made the same point in S.1.10.39; nec redeant iterum atque iterum spectanda theatris (these [his satires] should not come back again and again to be seen on stage). About twenty-five years later he still held the same opinion $^{50}$. In 12 or 11 B.C. he wrote a lengthy passage about three forms of poetry in his Epistula ad Augustum (Ep.2.1.156-218) in which he asks Augustus to look favourably on his art, which is poetry for private reading (lectori credere) (to entrust themselves to a reader) (2.1.214). In his earlier Ep.1.19, written between 23 and 19 B.C., he expressed similar feelings. In the lines 41-44 he says: spissis indigna theatris/scripta pudet recitare [...]'/si dixi, 'rides,' ait, 'et Iovis auribus ista/servas (If I said, 'I feel ashamed to recite my unworthy work in your crowded theatres,' says he 'You are merry, and preserve your work for the ears of Iove [Augustus]'). At the end of his life, when he wrote his Ars Poetica, he again poured scorn on the writing for large audiences and showed to be dismissive of the taste of large crowds, be it in the theatre or in someone's townhouse. In Ars.212-213 he writes: indoctus quid enim saperet liberque laborum/rusticus urbano confusus, turpis honesto? (What taste indeed would the man, ignorant and just finished with his hard work, have, a peasant mixed up with a man from town, the man without breeding with the respectable?). Lowrie $(2009,11)$ takes a similar line when she argues on the ground of the opening line of the first Roman Ode: "When Horace sets a premium on poetry"s aesthetic quality, he makes a similar gesture against entertainment in favour of a higher standard that separates him from popular culture (odi profanum vulgus (I despise the vulgar throng), Odes 3.1.1).”

The passages from Horace discussed above tell us, firstly, that large-scale recitations (spissis theatris) of poetry took place and that Horace detested them. Secondly, that he did not have much regard for the typical theatre crowds and did not want to cater for their tastes (Ep.1.19 and 2.1). Thirdly, that he was lucky as he could read his poetry to auribus Iovis, Augustus' ears. Propertius writes also obliquely about his preferred audience in the sixteenth Elegy of the third book (PROP.3.16.2930), where, discussing his burial place, he expresses his wish to be remembered as a poet who was read by a select group of friends and admirers.

Probably as a result of the new political situation, after 30 B.C. the composition of the Senate changed considerably, and the traditional political rhetoric, practiced by for instance Cicero, gradually disappeared. Rhetoricians had developed the practice of declamation, and when the opportunity for political oratory in the Senate dried up, declamation became a successful form of entertainment. Poets followed the example

50 Quinn (1982, 146, note 232), argues that Horace may have used the words contentus paucis lectoribus in S.1.10.74 as a way of answering public criticism of his fourth Satire and that the words do not represent his preferred kind of audience. This is unlikely, as Horace repeats his preference several times during a period of 25 years or more. 
of rhetoricians and sought large live audiences (White, 1993, 59-63; 2005, 322-323). White $(1993,60)$ quotes Seneca (Maior) who testifies in his Controversiae (Con.4.2) that in the 30s or 20s Pollio "became "the first of the Romans to recite his works to an invited general audience.””

In the last chapter of this book the question whether Vergil's work was part of a programme of propaganda will be briefly discussed. At this stage, I wish to make two points about his - and likewise other Augustan poets' - audiences. My first point is that the manner in which works of poetry were selected and received by these audiences did not create ideal conditions for Octavian's and later Augustus' putative propaganda. These people had other ways of forming their opinions and they chose their allegiance on the grounds of their political and social interests. It is doubtful that these men were easily convinced by the poets to either adopt or change a long-held view. I suspect that the convictions of these people were not a result of information, but had been formed by their class, their family and their position. In addition, the works of the poets were merely a small part of the total of information which they received, and probably not the most important part. This brings me to my second point: the growing auctoritas of the princeps. As time went on, Augustus' rule grew firmer, which meant that he became more and more a force to be reckoned with. His greater authority was not just a function of his position, but also of his personality, and many people within the elite were starting to appreciate the peace and stability that he had brought (Galinsky, 1996, 10-41). It is not inconceivable that many began thinking along the same lines as Augustus and actually approved of his actions. These men did not need any propaganda. In the chapters to come, which deal with Vergil's poetry, I will argue that there are clear indications that over time Vergil adopted a similar acceptance of the princeps.

In summary, the conclusion about the nature of the audience or readership of poetry is that, in general, only the members of the elite could read, and that for most other people the usual way of receiving information was through oral channels. The distribution of books was an expensive business, and therefore only members of the upper classes could afford to buy them. This meant that poetry circulated only within a small circle of people. Poems were used for private reading or for recitation in small gatherings of members of the political and intellectual elite for whom poetry was not the most likely means of forming their opinions. According to White (1993, 60 ) the poets acted in large-scale recitations of poetry as literary performers with the "ostensible motive to test critical reaction to work in progress." There is no evidence that these were used as a platform to deliver political messages.

\subsection{Patronage Or Amicitia?}

When examining propaganda by the poets of the first century B.C., their position in society and their "patronage" have to be considered, as these have a bearing on the 
issue of their independence. The social background of the poet, his way of raising an income, and the nature of the system in which the "patrons" and the poet operated are all relevant ${ }^{51}$. The word "patronage" has become the common expression in secondary literature to describe the relationship between a wealthy man and a poet in Augustan Rome and later. For the purpose of this study the nature of these relationships need to be determined more comprehensively. White $(1978,78-79 ; 1993,32-34)$ pointed out that the word patronus is never used in Latin to describe the literary relationship. White $(1978,79)$ states: "A patronus is somebody who has manumitted a slave, the formally designated sponsor of a town or corporation, or a lawyer who has undertaken a defence. The word does not denote the man who maintains a circle of friends and dependants." The use of the word "patron" or "patronage" originated in the Middle Ages to denote the men and women who founded and endowed churches and who had rights of appointment over them. White, $(2007,196)$ remarks that Horace "applies the word [amicus] to these relationships [socializing with others] more than twice as often as all other terms combined, and without apparent regard for status differences. 'Friend' is how he describes himself in relation to, among others, his junior protégé Septimius [Carm.2.6.24], the influential knight Maecenas [Carm.3.8.13], the senators Pollio and Messalla [S.1.10.85-87], and the prince Tiberius [Ep.1.9.5].” In this section, I will explore whether the terms suggested by White, amicitia and amicus, are not a more appropriate way of defining the relationships between men in influential positions and poets than the terms patronage and patron. Most of the poets of Augustus' days were members of the elite. Several belonged to the equestrian class, namely Tibullus, Propertius and Ovid, and Vergil was probably an eques; in any case it is very likely that his father was a landowner. Horace was probably the son of a member of the upper middle class of a town in Apulia and it is not unlikely that he also had been admitted to the equestrian ranks. Horace himself provides us with evidence that his father and he were not poor. Firstly, in S.2.7.53-54, he lets his slave Davus refer to his status as an eques: tu cum proiectis insignibus, anulo equestri/Romanoque habitu (You, when you have thrown away your regalia, the knight's ring, and your Roman dress). Secondly, in S.1.6.76-78, he refers to his own expensive education: sed puerum est ausus Romam portare, docendum/artis, quas doceat quivis eques atque senator/semet prognatos (but he dared to take his boy off to Rome, to be taught those studies which any knight or senator would have his own children taught). Although Horace was an exception, he was probably not an isolated case $\mathrm{s}^{52}$.

51 Gold, 1982, 1987, 2012a; Tarrant (2000, 183); White, 1978, 1982, 1993, 2005 and 2007; Williams (1968, 41-46).

52 White (1993, 5-14, esp. at 8-12); White (1993, 211-222) (Appendix 1) gives an overview of the social status of the Latin poets from the third century B.C. to approximately 140 A.D., and White (1993, 223-265) (Appendix 2) presents the connections of the Augustan poets. See also Ross Taylor (1925, 161-170). 
Unlike in today's society, where paid work is standard for the elite, this was not common in late Republican and Augustan Rome and Italia. Equites and candidate senators had to satisfy a property qualification in order to belong to the senatorial ranks, and the required property was of such a level that one could live on it reasonably well. Therefore, for the elite not working was the norm, and it was this elite that supplied the leading politicians, army officers and intellectuals ${ }^{53}$. It goes without saying that for the rest of the population a life of hard toil, if not slavery, was the norm. The leading classes and their extended families lived a comfortable life in townhouses in Rome and other cities, supported by a great number of servants and surrounded by a large retinue who were dependent on them in one form or another. In addition, most had one or more estates in Italia and lived the life of the landed gentry. The large estates could accommodate many hundreds, including members of the family, tenants, servants and slaves. The economic and social relationships at the level of the extended family encouraged mutual dependencies of the family members, where the services of many were bartered for food and protection by the few. The result was that in the economic unit of the family barter was the norm, just as this form of economic exchange was common in many parts of society at large. Such was the economic environment which the poet knew and of which he was a privileged member. The nature of this membership, in particular being the amicus of the head or of a leading member of the family will be discussed below after some other economic aspects of being a poet have been considered.

Did the poet have any earning potential? The answer is clearly that this was not the case. Firstly, in a time when the mass production of books did not exist and where the markets for selling books were minimal, the turnover of the few booksellers and therefore the opportunity for the poets to generate an income were limited. A source of income was writing for the stage, particularly for pantomime, which had become popular. However, this was not regarded a serious occupation for a serious poet and was frowned upon. In some cases, poets seem to have received payment for theatre productions, the best known case being Horace's Carmen Saeculare in 17 B.C.; but these cases were few and far between. Secondly, the poets came from and worked in an environment where payment for any service was uncommon. In particular, payment for intellectual services, such as writing poetry or oratory, was seen as demeaning, as it brought the artist or professional down to the level of a trader. Thirdly, as argued above, most of the poets did not need any payment for their work anyway, as they had sufficient income from other sources, especially Vergil and Horace, who were relatively rich. White $(2007,198)$ makes some interesting points with respect to Horace's financial position: “about four years before they [Maecenas and Horace] met, Horace had already wangled a pardon for fighting at Philippi, and

53 Veyne (1990, 5-69, esp. at 46-54, and 293-482). In his book, which concerns euergetism and the gift economy, he gives a detailed description of the social and economic environment. 
a salaried clerkship that installed him in 'the status group which lies just below the rank of eques.' Subsequent largesse from Maecenas and others is best seen as an enhancement of his income rather than the foundation of it." 54

The ancient sources tell us little about the precise nature of patronage at the end of the first century B.C., but it is unlikely that the relationships between the poets and the members of the Roman elite fit the patronus-cliens model. Although the economic and social background of a rich and often influential man differed greatly from that of a poet, the special bond between the two was generally founded on amicitia. In this section, the concept of amicitia will be discussed in more detail and will be set against the model of patronage. As argued above, the poets belonged broadly to the social upper class and moved as easily within this group as orators, lawyers and philosophers did. Charging for services rendered was not done, and a different but much more subtle mechanism transferred forms of recompense from the wealthy and influential to the professionals. White $(1982,56)$ says the following about this ${ }^{55}$ :

At least in Rome, these professions involved not simply the independent pursuit of an art or discipline but engagement in the life and interests of well-to-do society. Their practitioners provided services which beguiled the leisure or abetted the business of the leading citizens. By these services they established ties of amicitia which yielded far greater rewards than any system of fees or commissions would have done. Testamentary bequests, gifts of cash or property, and large loans on easy terms might fall into the lap of a rich man's friend. [...] The exchange of gifts and benefits had an important and well-defined place in the Roman code of friendship; and the wealth which accumulated in the hands of the rich during the early empire gave them rare means of putting in practice the virtue of liberality.

Amicitia therefore was more than just mere affection; Brunt (1988b, 355) notes that it bound people together "in bonds of obligation and honour." Amici did not take for granted that they were members of the same social set or held the same political conviction. Brunt (1988b, 356) also states that "Amicitia often purports to describe sincere affection based on a community of tastes, feelings and principles, and taking the form, where opportunity permits, of continuous and intimate association." There is often a shared intellectual interest and familiarity between the members of a circle of amici. Amicitia is not the same as clientela; the latter is generally based on a difference in social status and a cliens pays respect to his patronus and there is no feeling of being equals. A cliens is expected to fulfil his duties for his patronus in return for his protection.

54 Armstrong (2010, 13-14) presents some estimations of the wealth of Vergil and Horace. He asserts that both men easily met the property requirements to be eques or senator; "Vergil, another rich knight, died worth twenty million sesterces, richer even than Atticus [who was very rich]." See also White (2007, 197-198); Williams (1995, 295-296).

55 See also Brunt (1988b, 351-381); DuQuesnay (1984, 24-27); White (1993, 3-34); Gold (2012a, 303-310). 
Descriptions of this form of amicitia can be found in several works of the Augustan poets, such as Horace's Odes and Satires and Propertius' poetry ${ }^{56}$. A good example is the following selection from the Odes. The opening lines of the Odes testify to Horace's feelings of friendship for Maecenas; Carm.1.1.1-2, a dedication to Maecenas, reads: MAECENAS [...],/ o et praesidium et dulce decus meum, (Maecenas, my protection, my pleasure and my glory). In Carm.1.20.1-5, Horace invites Maecenas to drink wine with him $^{57}$ :

VILE potabis modicis Sabinum

cantharis, Graeca quod ego ipse testa

conditum levi, datus in theatro

cum tibi plausus,

care Maecenas eques,

(A cheap Sabine you will drink from ordinary cups, a seasoned wine that I myself sealed with pitch in a Greek jar on the day when you were given an applause in the theatre, dear knight Maecenas)

In this short poem of twelve lines, Horace expresses his feelings of amicitia towards Maecenas. He offers him good wine, that has been stored away since the day of Maecenas' return to public life after a dangerous illness. This shows how much Maecenas had been in the poet's thoughts.

In Carm.2.17.3-4, which describes that the destinies of Maecenas and Horace are linked,one reads: Maecenas, mearum/grande decus columenque rerum (Maecenas, you are the great glory and pillar of my existence). Further in book 3, in Carm.3.16.2930, Horace voices his joy with the Sabine estate, a "gift" by Maecenas (see below): purae rivus aquae silvaque iugerum/paucorum et segetis certa fides meae (A stream of clear water, and a few acres of woodland, a promise of my cornfield that never fails). In the Ode to Maecenas (Carm.3.29.25-26, 32-34) Horace expresses his concern for Maecenas' well-being:

tu civitatem quis deceat status

curas et Vrbi sollicitus times

[...]. quod adest memento

componere aequus; cetera fluminis

ritu feruntur,

(You trouble yourself about what form of government is suitable for the state, and being anxious for the capital you are fearful of [...]. Do not fail to put right what arises with even mind. Everything else is taken away like a river does)

56 See also Heyworth (2007b, 102-103), who gives a different view concerning Propertius.

57 The Loeb edition has clare in line 5, and the translation given is: 'Maecenas, illustrious knight.' 
Horace tells his friend not to fret about matters of state and counsels him to take life more calmly. In Carm.4.11.18-20 he expresses joy for the celebration of Maecenas' birthday: ex hac/ luce Maecenas meus adfluentis/ordinat annos (from this day my dear Maecenas records the increase of his years).

Yet another source of the amicitia of Horace and Maecenas is a passage of Suetonius in his Vita Horati 2.2 (Rostagni, 1944, 112-113):

Maecenas quantopere eum dilexerit satis testatur illo epigrammate:

$\mathrm{Ni}$ te visceribus meis, Horati,

plus iam diligo, tu tuum sodalem

nimio videas strigosiorem;

sed multo magis extremis indiciis tali ad Augustum elogio: "Horati Flacci ut mei esto memor". (How much Maecenas loved him is demonstrated sufficiently by this epigram: If I do not love you, my Horace, more than my own flesh, you may consider your comrade very much poorer than a scrag; But he said this much more strongly to Augustus in this short sentence in his last will: “Remember Horatius Flaccus as much as you will me.”).

Finally, in S.1.5.40-42 Horace describes the value he attaches to being in the company of friends. The party is on the way to Brundisium to attend a meeting between Octavian and Mark Antony. Maecenas has joined them early and a few days later the other amici arrive. About the reunion with the latter, among them Vergil, he writes:

Plotius et Varius Sinuessae Vergiliusque

occurrunt, animae qualis neque candidiores

terra tulit neque quis me sit devinctior alter.

(Plotius and Varius meet us at Sinuessa, and Vergil, men such as neither the earth bore brighter, nor to whom another is more devoted than I)

As for Propertius, it is not certain whether his patron was a Volcacius Tullus, nephew of L. Volcacius Tullus, who was consul in 33 B.C., or Maecenas. I concur with Heyworth (2007b, 95-97, 103) that Propertius did not write seriously about any patron at all. Heyworth $(2007 b, 96)$ says: "In fact there is nothing to suggest closeness between Tullus and Propertius." and "my conclusion is that Tullus is intended to be read not as a real patron in either book [Elegiae book 1 and 3] but as a poetic imitation of one.” In Elegia 1.22.2, Propertius refers to his amicitia with Tullus. Heyworth (2007b, 98), however, pours scorn on this amicitia and sees Tullus as "scarcily more than an acquaintance, not a life-long friend" of him ${ }^{58}$. Propertius refers in only two poems

58 Heyworth (2007a, 94, note 57) discusses the relationship between Propertius and Tullus. Although he does not address explicitly the question of patronage versus amicitia, I interpret his view on the relationship of the two men as a neutral one, that is, neither a patronage nor an amicitia. He states: "there is no adequate evidence to suppose the patronage of Tullus was important to Propertius: he explicitly rejects the opportunity to accompany him as part of his uncle's cohors in I vi, and in other poems in which he features ( $\mathrm{i}$, xiv, xxii; III xxii) the relationship is one of distance and contrast, not 
(Elegiae 2.1 and 3.9) to a relationship with Maecenas. Heyworth $(2007 \mathrm{~b}, 103)$ states that "it seems to me bizarre to base an unquestioning belief in Propertius's acceptance of Maecenas's patronage on such a foundation."

Thus, generally the poets were part of circles of friends, and belonged to the retinue of members of the Roman elite, together with other intellectuals who had not wished to pursue or had not been accepted in a political or judicial career ${ }^{59}$. Although gifts from the magnates were forthcoming, as Maecenas' gift of the Sabine farm to Horace shows, it was not financial support that the poets expected. In a barter economy such as the Roman one, the transfer of goods was common, and people were used to this form of exchange, but this is not to say that I see the gift as a form of payment for services rendered. Bowditch $(2010,56)$ discusses this system of benefaction and states the following:

In many ways, the Roman system of benefaction, and its subset of literary patronage, displays features of what anthropologists analyze as a "gift economy" (Veyne 1990; Dixon 1993; Bowditch 2001: 31-63). These characteristics include expenditure for the purpose of establishing prestige and status, the social cohesion that arises from gift-giving, an obligation to make a return gift, a perpetual disequilibrium of indebtedness - who is more indebted to whom? - and, perhaps most tellingly, a delay between an initial gift and its reciprocation, a temporal lag that, as Bourdieu points out (1977: 171), serves to mystify the economic aspect underlying an ideology of voluntarism in this form of exchange.

Murray (1990, vii-xxii), in his introduction to the translation of Veyne's Le pain et le cirque, notes that Veyne rejected rightly the use of modern economic theories for understanding ancient economic structures. Murray (1990, xv) states that Veyne understood that interpretations based upon modern theories

do not correspond to the perceptions of those [in ancient societies] engaged in these [economic] activities, and because they do not explain either the specific forms of social response or the ways such forms change in history. These were the arguments that led Veyne to reject modern theories, and to assert the difference, the essential otherness, of ancient economic organization [from ours]. In order to understand ancient economic history, we must forget economics.

intimacy and respect." Gold (2012a, 310-314, esp. at 313) shades the traditional view of Maecenas' patronage of Propertius. She states: "Thus the patron here [PROP.2.1 and 3.9] functions doubly, in both a poetic setting, as a theme for Propertius' poetry and his Muse, and as the historical figure to whom this poetic gift might be presented." (my emphasis).

59 White (1993, 35-63) gives a list of recorded friendships of poets. To the circle of Maecenas belonged: Domitius Marsus (latter half of first century B.C.), Fundanius (comic poet), Horace, Melissus (comic poet), Plotius Tucca, Propertius, L. Varius Rufus (latter half of the first century B.C.), Vergil and the brothers Visci. To the circle of Messalla Corvinus belonged: Horace, Ovid, Sextilius Ena (latter half of the first century B.C.), Sulpicia (late first century B.C.; in the Tibullan corpus there are some poems about a romance; see White, 1993, 91), Tibullus, Valgius Rufus (consul in 12 B.C.; see Horace's Carmen 2.9) and Vergil. 
This view has much to commend it, and the Roman gift economy can be seen as a development of the original Greek concept of public euergetism. In the Greek polis, giving to the community was a regularly occurring act of social responsibility ${ }^{60}$. This was also the case in Roman society, but in addition another group of receivers appeared: clientes and amici. Murray (1990, xiv) explains that

A gift economy is not one based on gift exchange: that would be a society half-way to becoming [economically speaking] "rational" in our sense [...]. The first essential in a gift economy is that return, reciprocity, should be unequal and incommensurable: I give to you because you cannot give to me, being poor; or I give to you so that you may give to me something quite different, incapable of being measured against my gift.

According to Bowditch (2001, 22-23, 31-63; 2010, 53-74) the rich elite, the "patrons" (rather amici) of the poets, expected the companionship of the latter and a place in the poet's verse. One might rightly ask whether the gift of an estate in the Sabine hills is not rather excessive compared to the return gift of being the addressee in a few poems or of being in the presence of poets ${ }^{61}$. However, the nature of this "gift" is often misunderstood. Maecenas, who was at the centre of power, "gave" the villa at a time when much property was being expropriated, for various reasons, and perhaps Horace's Sabine estate was one of such properties. The ownership of the villa was presumably not transferred to Horace, but the poet enjoyed the free use of the property.

Through their association with the powerful, the poets hoped to receive recognition and publicity for their work. In these "salons", they recited their work, but presumably also discussed all kinds of subjects and their opinions might be sought once they had acquired the confidence of their amicus. Consequently, it is not surprising that the poets expressed their views in their poems.

Obviously, this raises the question about the independence of the poets. Maecenas, for instance, may have encouraged poetry in praise of Augustus, and White $(2005,331)$ states: "Maecenas' implication in the panegyrical slant of Augustan poetry is likely." 62

60 Veyne (1990, 5-69; 293-482); see also Mauss, 1954.

61 Gold (2012a, 309-310); White (2007, 198, note 13), quotes Bradshaw (1989, 160-186) with respect to Maecenas' gift of the Sabine estate: "Bradshaw (1989) rightly insists that Horace does not unambiguously describe the Sabine farm as a gift from Maecenas and that the scholiasts, who do, cannot be proved to have possessed information independent of Horace's words. Cairns (1992) 107-9 is equally right to say that the conventional view may nevertheless be correct."

62 Anderson (2010, 34-52): this essay concerns the amicitia between Horace and Maecenas. The author $(2010,51)$ states that "book 1 of the Epistles [of Horace] is a decisive refutation of the theory of Horace's incorporation in the so-called Circle of Maecenas," and "he [Horace] is polite and friendly to Maecenas in three letters, but Maecenas does not control them, and indeed Horace presents himself from the start as choosing the genre [Epistles] in spite of Maecenas' wishes.” Hekster (2009, 48-50), and White (2005, 331) do not regard the Augustan poets as propagandists, but emphasise the panegyric aspects of their poetry. 
This does not make the poets dependent lackeys, and I differ from Bowditch, who argues that Horace traded his independence away for the gift of the Sabine estate. She (Bowditch 2001,15) argues that "philosophers and poets alike avoid the language of patronage, and the corresponding diction of clientela or clientship, when describing relations between those of elite social status. Literary patronage, as I discuss in more detail below, was referred to almost exclusively in terms of amicitia or friendship." In her (Bowditch 2001, 16) opinion, Horace was only autonomous on "the level of poetic representation," and he felt all the "obligation - the sense of debt, gratitude, and compulsion to return" - that the gift economy would impose. In a recent (Bowditch 2010, 73) essay she also states that "whether in response to such power [the power which compels, not only if it invites but even if it beseeches] or to the more subtle persuasion of gifts, Horace wrote poems that cannot be dissociated from the socioeconomics of patronage." She overlooks, however, Horace's' independent attitude, which is evident through the contents of the many critical poems which he wrote until the end of his career. Bowditch (2001) analyses a total of 49 of Horace's poems: I consider 8 of these as critical, but she does not discuss the critical content of any of these ${ }^{63}$.

Contrary to what has often been stated, the involvement as an amicus in a circle of amici worked as a guarantee of their independence. As accepted members of the circle of friends, the poets, who were financially independent, were seen as having a contribution to make, and the writing of poems about political or social questions emanated naturally from their position of intelligent observers and participants in the arguments, and not from an order to write propagandist material. This is a very different picture than that of what Nadeau (2004) in the title of his book calls the "safe and subsidized" poet by a patron: the scenario of amicitia is far more subtle. It is part and parcel of the social relationships in the late Republic and the early Empire. As White $(1978,92)$ says: "Once established in the amicitia of a rich man, poets received material benefits which were the perquisites of friends rather than the due of poetry."

Of course, there are other points of view. For instance, several scholars argue that Maecenas and Augustus put pressure on Horace. Watson (2003, 2-3) states that Horace's introduction to Maecenas' circle in 38 B.C. gave "obligations to trade mutual benefactions - on Maecenas' side the treasured gift of the Sabine farm," causing an "ideological sea-change which Horace now undergoes." In the planned sequel

63 Bowditch (2001, 278-280). She has analysed 4 Sermones (1.1, 1.6, 2.2 and 2.6, of which 2.2 is critical), 3 Iambi (1, 7 and 16, of which 7 and 16 are critical), 28 Carmina (1.1, 1.2, 1.3, 1.9, 1.12, 1.16, 1.17, 1.20, 1.22, 1.30, 1.35, 1.37, 2.1, 2.7, 2.13, 2.16, 2.18, 3.1-3.6, 3.22. 3.29, 3.30, 4.11 and Carm. Saec., of which 1.35, 2.1, 3.6 and 3.29 are critical) and 14 Epistulae (1.1, 1.2, 1.7, 1.12, 1.13, 1.14, 1.16, 1.17, 1.18, 1.19, 1.20, 2.1, 2.2 and Ars Poetica, of which 2.1 is critical). I will discuss these in a planned sequel to this book on Horace's poetry. 
to this book I will argue that Horace remained critical of Octavian/Augustus after 38 B.C.. Brink (1982, 558-560) sees a new period in Roman literature after 19 B.C.. He considers the withdrawal from public life of Maecenas as one of the significant factors of Horace's writing “official and panegyrical verse” (1982, 559). In the planned sequel I will also argue that Horace probably wrote his panegyrics for Augustus because he genuinely believed that the princeps brought peace and stability.

The issue of freedom of speech and libel laws in Augustan Rome is also relevant in this context. Raaflaub (2004, 57-58), discussing Cicero, touches on the exclusive character of the Roman aristocracy and their ways of dealing with power. Although the essay is about freedom of speech, the conclusions may also be relevant for the restrictions which the Roman elite put on dissenting opinions, thus making the poets feel less free to express their points of view. Raaflaub $(2004,57)$ states:

It [freedom of speech] was not, however, a primary political value in aristocratic communities, even if at least the political elites claimed it as their natural right, based on their social distinction. [...] What mattered to them was that they were part of an exclusive group who shared power and government and in that sense were equal - even if within this framework they competed fiercely for primacy.

Rutledge (2009, 41-42) makes a relevant commentary from a sociological viewpoint:

Hence under Augustus it seems that libel laws - which had existed previously, though perhaps with less rigorous application - were at last enforced. In general there was a pecking order: plebs must not attack their superiors; senators must not attack one another; nor must they attack the princeps - though again some of this was contingent on the context in which a particular remark was made. The relationship between the addressor and addressee, the social milieu, or the political situation could variously determine or qualify what could and could not be said.

Pagán $(2004,382)$ remarks: "Rather, in a way familiar even to us who prize freedom of speech, there was a growing acknowledgement of a gentlemen's agreement as to what can and cannot be said," In the next chapters I will argue that Vergil, who moved in the intellectual and social elite, claimed similar rights on freedom of speech as the members of the aristocracy.

\subsection{Summary}

Before drawing the different sections of this chapter to a close, I will quote the final passage of a book by Woodman and West $(1984,195)$ as I believe that this summarises and supports my conclusions of the relevant contextual factors:

We set about this collection [Poetry and politics in the age of Augustus] in the hope that it would shed some light on an interesting subject which is important both to literary scholars and to historians. Our contributors show that easy distinctions such as 'Is this poetry or propaganda?' 
and 'Are the poets sincere or are they puppets?' take us nowhere. The matter is complicated by the genuine friendships within the circle of writers and principes uiri, by the delicacy with which Maecenas treats his poets, by the recognition that Augustus had restored peace, order and idealism to a society which had lost them, by the significance of the form a poem takes and of the time when it was written. There can have been few ages in which poets were so intimately and affectionately connected with the holders of political power, few regimes with a richer iconography, few poets so profoundly moved by a political ideal and so equipped to sing its praises with subtlety, humour, learning and rapture. The reader of these poems needs a touch of all these.

The subject matters upon which Woodman and West touch have been broadly discussed in the present chapter. The conclusions of my chapter are that Vergil, Horace and Propertius had lived through a time of great political and social upheaval and change, and in Octavian saw the first signs of some stability. When peace arrived, new intellectual and artistic values in poetry emerged, such as a high degree of involvement in contemporary issues. References to mythical and historical subjects were used widely in the Augustan visual media and in poetry to present messages, often with a political content, about contemporary events. The poets were involved in circles of amici and belonged to the retinue of members of the Roman elite, together with other intellectuals. The reading or the recitation of their poetry took place in these privileged circles, where the poets' views and commentary on political matters were neither exceptional nor, perhaps, the most authoritative. One might therefore seriously doubt whether poetry with a propagandist character was an effective means of communicating political messages within the Roman elite. 